\title{
Raised reef on Larak suggests Acropora dominance on the Persian Gulf coral reefs since the Pleistocene
}

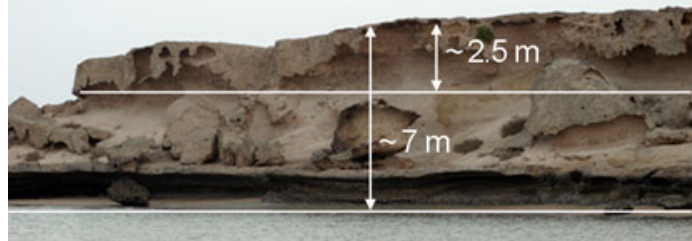

a

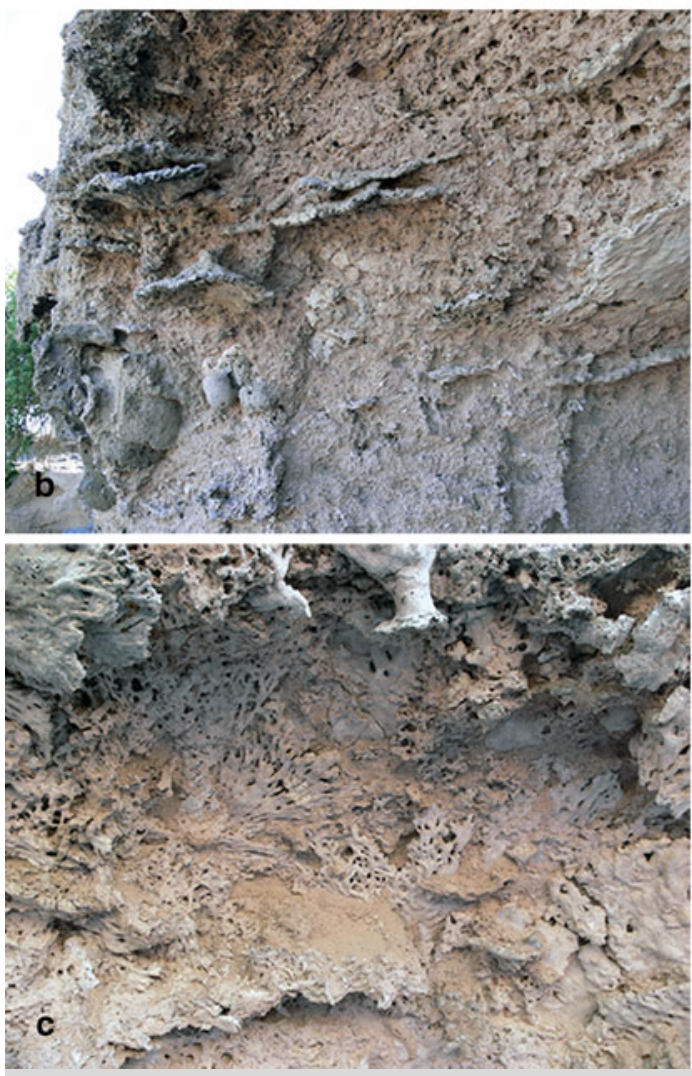

Fig. 1 a Overview of the outcrop. b-c Details of Acropora tables in growth position. $\mathbf{d}$ Acropora dominance continues to the very top of the section, where it becomes obscured by heavier diagenesis

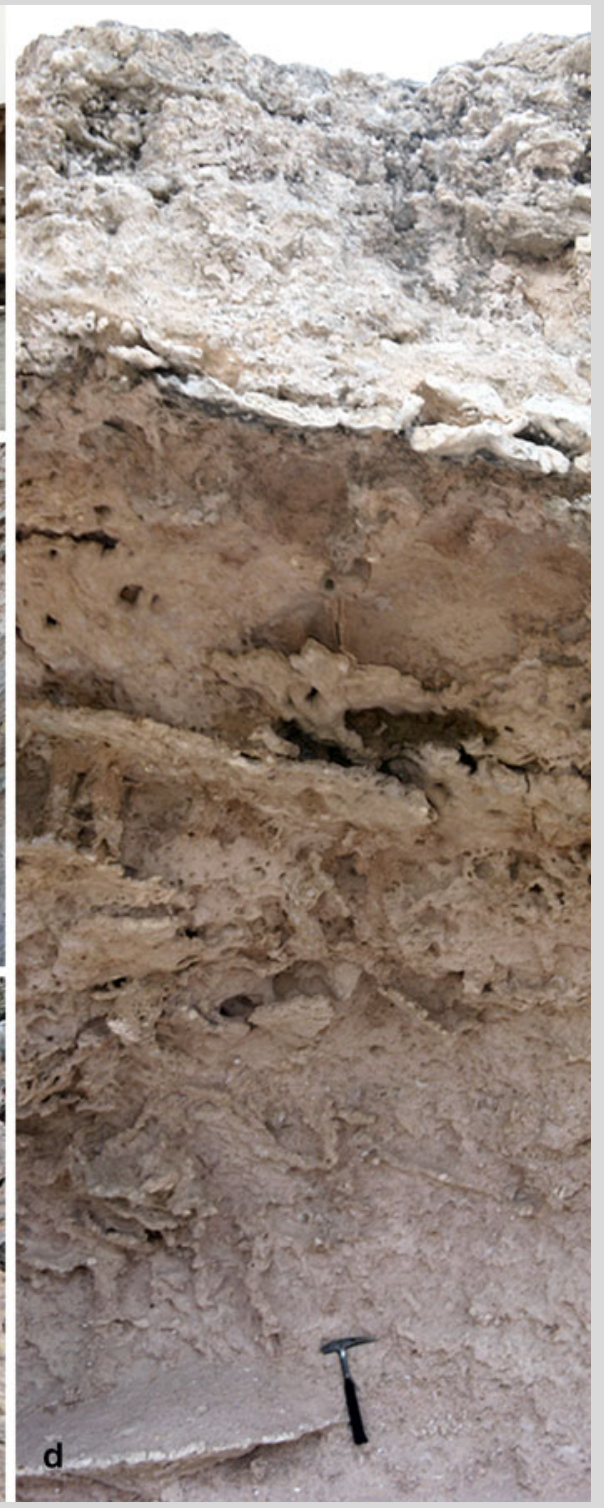

We show hitherto undescribed raised coral frameworks exposed at the NE coast of Larak (Iran), a salt diapir island, located in the Strait of Hormuz, Persian Gulf (Fig. 1a). The entire outcropping section i $\sim 7 \mathrm{~m}$ thick. At least two fossil reef sequences were recognized, separated by clastic sediment layers: one near mean sea level (MSL) and the other one $>4 \mathrm{~m}$ above MSL, the upper $2.5 \mathrm{~m}$ of which consist mostly of Acropora plates of the clathratal downingi group (Fig. 1 b-d). Preliminary $\mathrm{U} / \mathrm{Th},{ }^{14} \mathrm{C}$ dates are problematic but suggest an upper Pleistocene age ranging from 30 to $150 \mathrm{ka}$. This is comparable to similar outcrops at nearby Hormoz and Qeshm (Bruthans et al. 2006). Outcrops suggest several consecutive layers of Acropora dominance, comparable to the situation in the modern Gulf until recently, but not yet reported from other known raised deposits in the region (Pirazzoli et al. 2004; Bruthans et al. 2006).

The Larak outcrop allows us for the first time to clearly establish that Acropora has been a dominant member of Persian Gulf coral assemblages since the Pleistocene. While Acropora remain common in the northern Gulf, rapidly recurring bleaching events caused their abrupt decline in the southern Gulf (Riegl et al. 2011). Their dire situation in the southern Gulf may herald an interruption of long-term ecological persistence of Acropora dominance. This is eerily similar to the situation observed in the Caribbean (Pandolfi and Jackson 2006).

Open Access This article is distributed under the terms of the Creative Commons Attribution License which permits any use, distribution, and reproduction in any medium, provided the original author(s) and the source are credited.

References

Bruthans J, Filippi M, Geršl M, Zare M, Melková J, Pazdur A, Bosák P (2006) Holocene marine terraces on two salt diapirs in the Persian Gulf, Iran: age, depositional history and uplift rates. J Quat Sci 21:843-857

Pandolf JM, Jackson JBC (2006) Ecological persistence interrupted in Caribbean coral reefs. Ecol Lett 9:818-826

Pirazzoli PA, Reyss J-L, Funtugne M, Haghipour A, Hilgers A, Kasper HU, Nazari H, Preusser F, Radtke U (2004) Quaternary coral-reef terraces from Kish and Qeshm Islands, Persian Gulf: new radiometric ages and tectonic implications. Quaternary Int 120:15-27

Riegl B, Purkis S, Al-Cibahy A, Abdel-Moati M, Hoegh-Guldberg O (2011) Present limits to heat- adaptability in corals and population-level responses to climate extremes.

PLoS One 6/9.e24802: 1-8

K. Samimi-Namin $(\bowtie)$

Netherlands Centre for Biodiversity Naturalis, P.O. Box 9517, 2300 RA Leiden, The Netherlands

e-mail: kaveh_s_n@yahoo.com

K. Samimi-Namin

Iranian National Institute for Oceanography, P.O. Box 14155-4781, Tehran, Iran

B. Riegl

National Coral Reef Institute, Oceanographic Center, Nova Southeastern University, Dania Beach, FL 33004, USA

Received: 27 January 2012/Accepted: 19 April 2012/Published online: 9 May 2012

Coral Reefs (2012) 31:763

(C) The Author(s). This article is published with open access at Springerlink.com 2012

DOI $10.1007 / \mathrm{s} 00338-012-0908-\mathrm{x}$ 